
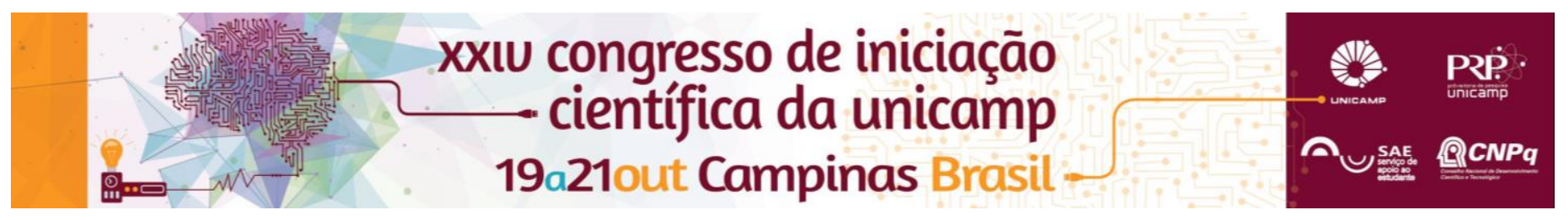

\title{
Manifestação Pacífica: Sentidos do Político da Linguagem
}

\section{Deborah Pereira*}

\section{Resumo}

O trabalho investiga os diferentes modos de nomear "Manifestações de Junho de 2013" buscando compreender, principalmente, quais memoráveis estas enunciações suscitam e o jogo da mídia em (des)legitimar as Manifestações por meio da materialidade enunciativo-discursiva. Para isso, analisou-se as notícias disponíveis da plataforma G1 de Notícias do Estado de São Paulo a respeito das manifestações no período de junho de 2013. Como grande aparato teórico, debruçamo-nos em Guimarães (2002), a fim de compreender a noção de Acontecimento, inserida dentro das teorias de enunciação já que o autor toma "enunciação como acontecimento no qual se dá a relação do sujeito com a língua" (p. 8).

\section{Palavras-chave: \\ Manifestações de Junho de 2013, Semântica do Acontecimento,Nomeação}

\section{Introdução}

Em Junho de 2013, o cenário público brasileiro foi tomado por uma novidade: grandes manifestações eclodiram nas ruas das principais cidades do país, mobilizando um número de pessoas comparável aos protestos das décadas de 1980 e início de 1990, com o impeachment do então presidente Collor de Mello. Há uma grande disputa, , em relação ao significado das manifestações e sobre o que elas representam para a conjuntura política nacional. Deste modo, este trabalho propõe fazer uma análise, sob a luz da linguagem e das teorias semântico-enunciativas, dos atos de nomear este evento e quais efeitos de sentido eles podem produzir, observando o que deles se pode tirar de interpretável.

O principal objetivo desta pesquisa é contribuir, a partir da análise de um fato de linguagem, para o entendimento do funcionamento político do dizer no acontecimento da ida às ruas em junho de 2013 compreendendo a temporalidade dos dizeres (da mídia jornalística) e seus memoráveis.

\section{Resultados e Discussão}

Este projeto tinha como foco investigar o funcionamento da formação nominal "Manifestação Pacífica" em diferentes plataformas da web (redes sociais, jornais, blogs, etc) e num período de tempo que se estendia de maio a outubro de 2013. No entanto, em reunião com a orientadora, verificou-se que esta pesquisa tão ampla e que utilizasse tantos sujeitos e plataformas distintas talvez não tivesse tanto rigor científico. Assim, optou-se por utilizar como corpus apenas as notícias do Jornal G1 a respeito das Manifestações durante o mês de junho de 2013, restringindo a pesquisa, como dito na sessão anterior, à análise dos diferentes modos de nomear "Manifestações de Junho de 2013"

Deste modo, metodologicamente, fez-se uma pesquisa de todas as notícias sobre as Manifestações disponíveis do Jornal G1 do Estado de São Paulo durante o mês de Junho. Com isso, identificou-se os diferentes modos de nomear 'manifestações', organizando-os considerando a ordem cronológica para melhor análise dos mesmos. Também foram feitas leituras de teorias semânticoenunciativas e sobre as Manifestações no Brasil.

Como aparato teórico da pesquisa, utilizou-se fortemente Guimarães (2002) e a noção de Acontecimento. Para o autor, um nome designa algo construído simbolicamente (p. 91). Na análise de nome de ruas, Guimarães demonstra que os nomes não apenas referem e designam (as ruas), mas também as identificam num processo social e histórico (p. 92), o de enunciar e, nesta instância, nomear conforma-se como um acontecimento. Do mesmo modo - mas com processos diferentes - as maneiras de nomear Manifestação no Jornal aqui trabalhado também produzem efeitos que ultrapassam a simples designação e carregam um sentido político, histórico e social.

Assim, verificou-se que no início das manifestações, palavras negativas e deslegitimizadoras do movimento eram as mais utilizadas para nomear o evento (vandalismo, tumulto). Identifica-se, assim, um memorável também negativo, que alia 0 ato de manifestar com a negação de uma ordem. Isto vai de acordo com Lima (2013, s/p) que conclui que a primeira reação da mídia e das autoridades foi de condenar e reprimir as Manifestações. Mais tarde, a partir do meio do mês de junho, observa-se uma queda no uso de palavras com carga negativa e verifica-se o movimento novo da mídia em tornar as manifestações legítimas e importantes meios de politização (surgem nomes como "movimento politico" e "ação de mobilização") e que, agora, estão dentro de uma ordem social ("protesto pacifico").

\section{Conclusões}

Foi possível perceber o jogo da mídia em tornar (des)legítima as Manifestações de Junho de 2013 através dos modos de nomeação deste ato político de ida às ruas. Ao identificarmos os memoráveis que cada grupo de nomes permitia, compreendeu-se melhor os embates políticos, históricos e sociais que o acontecimento de linguagem, inscrito na enunciação, instaura através dos atos de nomear.

\section{Agradecimentos}

CNPQ - Conselho Nacional de Desenvolvimento Científico e Tecnológico trabalho.

\footnotetext{
GUIMARÃES, E. Semântica do acontecimento Campinas, SP Pontes, 2002.

2 LIMA, V. As manifestações de junho e a mídia. Teoria e Debate. Ed. 113. 2013
} 